\title{
THE ROLE OF INDONESIA'S ECONOMIC DIPLOMACY IN THE DYNAMICS OF INDONESIA'S RELATIONSHIP WITH AUSTRALIA UNDER THE LEADERSHIP OF JOKO WIDODO (2014-2016)
}

\author{
Della Junita Evasari \\ International Relations, Universitas Kristen Indonesia, Jakarta, Indonesia \\ dellajunita3@gmail.com
}

\begin{abstract}
This study discusses the relationship between Indonesia and Australia that have been unstable. Both countries make efforts to transform the various challenges and potential conflicts into an arena of cooperation that is beneficial to both countries, which realized through the implementation of economic diplomacy. Economic relations between Indonesia and Australia are important for both countries, but the value not maximized. As neighboring countries are close together, the cost is likely to be optimized, seeing from the data of strong economic performance and complementary both countries. The purpose of this study is to determine the role of Indonesian Economic Diplomacy in the dynamics of Indonesia's relationship with Australia in the era of President Joko Widodo's Government (2014-2016). This research uses a qualitative research methodology with a descriptive analysis approach. The theory used is the theory of diplomacy and the concept of economic diplomacy. The results show three roles of Indonesian economic diplomacy in the dynamics of Indonesia's relations with Australia in the era of President Joko Widodo. First, it seeks to increase cooperation between Indonesia and Australia in the economic sector (exports, imports, and investments), tourism, and education. Secondly, to improve the relationship between Indonesia and Australia to be closer and reduce the tension/conflict between the two countries. Third, encourage complementary relationships and win-win relationships. One of the implementations of Indonesia's economic diplomacy with Australia is the Indonesia-Australia Comprehensive Economic Partnership Agreement (IA- CEPA), which is currently in the process of negotiating both countries. Successful cooperation agreements will reflect strong ties between the two countries.
\end{abstract}

Keywords: Economic Diplomacy, Indonesia-Australia, IA-CEPA, Free Trade Area

DOI: $10.33541 /$ sp.v19i2.1649

Sociae Polites : Majalah IImiah Sosial Politik

Faculty of Social and Political Science, Universitas Kristen Indonesia

ISSN 1410-3745 print/ ISSN 2620-4975 online

Volume 19, Number 2 (July - December 2018)

Pages 121-144 


\section{Introduction}

\subsection{Background}

Indonesia and Australia are two neighboring countries and have long-established cooperative relations in various fields. In essence, Indonesia is an essential country for Australia. Aside from being the closest neighboring country to the north, Indonesia is also the largest member of the Association of Southeast Asia Nations (ASEAN) in terms of population and area so that it can become a significant market share for Australia. In ASEAN membership, Indonesia has a vital role so that it can bridge Australia's trade relations with ASEAN member countries (Cipto 2010, 192).

Geographical proximity makes Indonesia and Australia feel essential to establish a relationship between the two, as confirmed in the 1997 Australia foreign affairs and trade white paper that relations between Indonesia and Australia are significant (White Paper on Australia's Foreign and Trade Policy, 1997). The assessment of the importance of Indonesia in white paper also reflects a strong element of sustainability. The book confirms that "Australia-Indonesia relations will always be important"; because Indonesia's strategic position is essential for Australia's trade routes, with its population and location in Southeast Asia, and the development and diversification of bilateral partnerships are noteworthy.

Cooperation between the two countries has expanded across broad strategic, economic, technical, educational, and cultural areas. The challenge is how to maintain and expand it. Indonesia is a significant financial and regional partner for Australia. Two directions of trade in goods and services make Indonesia the 12th largest trading partner and Australia's 11th largest export market (www.dfat.gov.au, 2016). Australia's investment in Indonesia gets valued at around \$ 10.9 billion in 2013. Austrade estimates that more than 400 Australian companies are operating in Indonesia, including the mining, agriculture, construction, infrastructure, finance, health, food and beverage, and transportation (DFAT) sectors. gov.au, 2014). Australia's strategic defense policy white paper uses language that further emphasizes that "Indonesia has a strategic significance that is unique to Australia" and will be a "key determinant of Australia's security in the future" (Chauvel 2005, 39). The journey of relations between Indonesia and Australia, which are two neighboring countries and have an important role, cannot be denied that the phenomenon gets often adorned with friction or tension. This phenomenon occurs because the two countries have differences in various ways.

The fundamental difference between the two countries is that Indonesia is a country that consists of many islands and inhabited by hundreds of millions of inhabitants, which in many ways are both diverse in ideology, culture, ethnicity, religion, and political attitudes. Indonesia has also experienced colonialism from other countries from the Netherlands, Britain, and Japan so that during the colonial period, the Indonesian people were laden with experiences of rebellion against the colonizers, which gave birth to militant characteristics. While Australia is a separate continent whose population is ten times smaller than Indonesia and the community comes from European immigrants who took over the continent from Aboriginal residents, not only experiencing differences in geographical terms, but also in terms of history, ideology, philosophy, and others.

It can get said that the relationship between Indonesia and Australia gets classified as a unique relationship; on the one hand, it promises various opportunities for 
cooperation, but on the other hand, it is also full of multiple challenges. This condition caused by many striking differences between the two neighboring countries, which are related to culture, the level of development progress, a political orientation, which also results in differences in priority interests. If seen from its history, Indonesia's bilateral relations with Australia since 1945 have always colored up and down graphs (Dugis 1997, 41). There was a period when relations between the two neighboring countries were so warm, close, and stable, but there were also moments when the relationship was cold, distant, and full of noise (Catley \& Dugis 1998, 52). The crisis, in which the general crisis followed by various remedial efforts made by both parties towards the point of stable closeness.

The tensions that have occurred so far make the two countries realize that the relationship between them is unstable. One Indonesian expert from Australia, Prof. Colin Brown, even compared bilateral relations between Indonesia and Australia like a roller coaster where relations between the two countries increased slowly but at some point will decline very quickly and, at other times, will increase again (Deputy Vice President 2008, 63). One issue that has always been a broad question of the public since the 2014 Indonesian presidential election campaign is how President Joko Widodo (Jokowi) manages Indonesian foreign relations.

The issue at the time was stealing the attention was related to the prospect of Indonesia's relations with Australia. Focus arose following the scandal of communication intercepts carried out by Australian spy agents against several highranking officials in Indonesia, including President Susilo Bambang Yudhoyono, president of the government before President Joko Widodo. The opening of this wiretapping scandal has angered the Indonesian government. Australia ignored the insistence of an apology, and this led to Jakarta calling home for a while the Indonesian Ambassador to Australia on 19 November 2013, as a form of strong protest against Australia's attitude. It did not stop there; the day after the ambassador's recall, Indonesia officially suspended the implementation of cooperation in the field of law and military (military and law enforcement collaboration). Indonesia's friendly relations with Australia, which during the two periods of President SBY's leadership, were marked by stability, this time again experienced a disturbance, characterized by ongoing diplomatic tensions (Dugis 2009, 59).

Nevertheless, the improvement effort seems to be carried out by both parties. Although for a while, Indonesia was without an Ambassador in Canberra, communication at the elite level continued. The results showed when Indonesia at the end of May 2014 decided to send the Ambassador back to the post in Canberra, which had been empty since November 2013. Not long after this, on 4 June 2014, the Australian Prime Minister Tony Abbott met with President SBY on Batam. One that was considered significant from the effort to normalize this relationship was the visit of Vice President Budiono to Australia in August 2014. However, the process of normalizing this relationship had not fully recovered as it was before the tapping scandal revealed.

Under the inheritance of the condition of "cooling" bilateral relations, President Jokowi rose to become the number one person in Indonesia. The presence of Prime Minister Tony Abbott at the inauguration of President Jokowi gave a clear signal that the Australian side was enthusiastic about improving bilateral relations with Indonesia. However, these signs of strengthening ties vanished following the decision of the execution of two Australian citizens sentenced to death for drug smuggling, Andrew 
Chan and Myuran Sukumaran. Strong protest by the government and the Australian public against the decision, as well as various other efforts made by the Australian government, did not shake Indonesia's decision. The climax was when President Jokowi rejected requests for clemency from the Australian side of the two death row inmates. The execution continued, and as a form of protest by the Australian government, the Australian Ambassador in Jakarta get withdrawn to Canberra. Relations between the two countries fell back to a lower point.

After that, various normalization efforts get carried out again. A month after being withdrawn, the Australian Ambassador resumed his post in Jakarta. Efforts to strengthen the relations between the two friendly countries would require time. Therefore, the two countries need to continue to make efforts to transform various challenges and potential conflicts into an arena of cooperation that benefits both countries, one of which is through the implementation of economic diplomacy. Economic diplomacy described as a package of activities related to cross-border economic activities (exports, imports, investment, loans, aid, migration, etc.) carried out by state and non-state actors in the international world. The role of economic diplomacy is becoming an increasingly important instrument element in foreign economic policy (Djumala 2014, 2). In this context, economic diplomacy can get interpreted as the use of political tools to gain influence in international negotiations to increase economic prosperity; and the use of economic impact to increase a country's stability (Ministry of Foreign Affairs 2015, 7). Thus, industrial relations can also play their role as an influential factor in political ties. In the era of President Joko Widodo's administration, from 2014 until now, President Joko Widodo gave directions to several Indonesian Ambassadors abroad that the president wanted economic diplomacy to be the main focus. The Ministry of Foreign Affairs is also focusing on increasing economic diplomacy through Indonesian representatives abroad. Included in the dynamics of Indonesia's bilateral relations with Australia, the role of economic diplomacy is felt to be essential to stabilize relations between the two countries.

\subsection{Research Question}

The formulation of the problem in this study is: What is the role of Indonesia's economic diplomacy in the dynamics of Indonesia's relations with Australia in the era of President Joko Widodo's administration (2014-2016)?

\section{Literature Review}

In research on the role of Indonesia's economic diplomacy in the dynamics of Indonesia's relations with Australia during President Joko Widodo's reign, researchers used the book "Australia's relationship with Indonesia: Geographical, Political and Security Strategy Factors," written by Sugiarti Sriwibawa, 1995, publisher of the University of Indonesia, Jakarta. This book explains about relations between Indonesia and Australia in the era of the Gough Whitlam government, mainly when Indonesia under President Soeharto's administration focused more on economic development than building military capabilities. Economic growth gets carried out through economic cooperation. Australia itself has army skills and technology that are relatively more than enough to prevent Indonesia. This book is a reference and comparison material on Indonesia's relations with Australia in different eras. 
The book titled "Indonesia and Australia: Challenges and Opportunities in Bilateral Political Relations," written by Chusnul Mar'iyah, was published by Granit, Jakarta, in 2005. This book can be a reference in understanding the relations between the two countries. From this book, it can get viewed that bilateral relations between Indonesia and Australia have challenges and opportunities that must be faced and dealt with within. The problem is that the differences between the two countries have different political views, causing friction or obstacles. The opportunity is, the proximity of the two countries geographically can be an opportunity for the two countries to integrate and work together more for mutual benefit. In examining the role of Indonesia's economic diplomacy in the dynamics of Indonesia's relations with Australia, theories, and concepts needed to analyze, one method used to explain is the theory of diplomacy and the economic diplomacy.

\section{- Theory of Diplomacy}

Sir Ernest Satow, in his book Guide to Diplomatic Practice, defines diplomacy as "the application of intelligence and tact to conduct of official relations between the government of independent states." Meanwhile, Harold Nicholson said that diplomacy showed at least five things. Namely, foreign policy, negotiations, the mechanism of the implementation of these negotiations, foreign service branches, and the abstract quality of meaningful gifts, including expertise in conducting international negotiations and in a wicked sense, include more devious tactics (Roy 1991, 1).

S. L. Roy argues that diplomacy that is very closely related to relations between countries is the art of promoting the interests of a country through negotiations in peaceful ways when possible, in dealing with other countries. If peaceful means fail to achieve the desired goals, diplomacy permits the use of threats or real force as a means of achieving its objectives (Roy, 1991, 5). The purpose of diplomacy, in general, is to meet the interests of a country. Diplomacy itself is a tool used by the state so that the country gets favorable results. Favorable results here mean that the objectives and interests of the country are guaranteed. For any country, the main aim of diplomacy is to safeguard its political and territorial freedom. But diplomacy is not just about fulfilling a country's political needs but also meeting its economic needs. Countries with an open financial system must always find ways to secure their business interests and oversee the development of other countries so that they can consistently compete. With the birth of the laissez-faire and the free trade system and the impact of the national economic emphasis, developed and underdeveloped countries have come across the fact that trade and finance can get used as the main tools of national policy. As a result, the achievement of economic gains has become an essential goal of diplomacy (Roy 1991, 10).

Experts share some of the same basic views regarding economic diplomacy. Roy, in his book Diplomacy, states that the economy is an integral part of modern diplomacy today. In other words, the economy no longer gets seen as a separate element of diplomacy. The second is, the end of the Cold War makes trade and economic factors used to influence the policies of other countries and help a country achieve its national interests. Third, in economic diplomacy, the state is not a single actor but also the roles of different actors such as the private sector, international organizations, and the community is needed to carry out a country's economic policy (Roy 1991, 128).

From several economic instruments, trade plays a significant role. Along with 
trade and commerce, the imposition of financial assistance sanctions has also become a vital diplomacy tool today. We can call it diplomacy through economics that is diplomacy, which is associated with economic factors (Roy 1991, 120).

Economic instruments get very widely applied in times of war and peace; international trade and international assistance used as diplomatic tools that make it easier in peacetime. During the war and the Cold War, various economic measures proved to get most effectively used as a tool to force opponents. The increasing role of international trade has an inevitable impact on diplomacy and diplomatic practices (Roy 1991, 121).

Several factors increase the role of the economy and trade in diplomacy, according to Roy. First is the threat of nuclear war has become a significant deterrent to the use of force to resolve disputes, especially if the interests of the major powers are involved. To determine differences not to fall into armed conflict, other actions, primarily industrial actions, are implemented to produce a solution that is beneficial to the dispute. The second is increasing interdependence between countries in economic matters so that the economy gains an essential position in diplomacy. The third is the politics of providing financial assistance from large states to smaller countries, while the latter is because the Cold War has led to the adoption of various economic measures as diplomatic tactics (Roy 1991, 127).

\section{- Economic Diplomacy}

Peter A. G. Van Bergeijk and Selwyn Moons (Bergeijk 2007, 37-54) define economic diplomacy, "the use of the full spectrum of economic tools of the state to achieve its national interest." Exports, imports, investments, aid, and free trade agreements as part of that economic diplomacy. There are two approaches in economic diplomacy, namely the commercial approach (Business End) and the political approach (Power Play End). A market approach is an approach that considers welfare issues because it deals with the prosperity of the people. While the political plan pays more attention to things like national and regional stability because if national and local security gets disrupted, it can shake the economy, and vice versa, economic diplomacy must prioritize the balance of national interests between welfare and national stability. Both approaches to economic diplomacy have forms, including Commercial Diplomacy, Trade Diplomacy, Financial Diplomacy, Inducements, and Negative Sanction (Kerr 2013, 210).

Commercial diplomacy is an activity that aims to encourage business development through a series of business promotion and facilitation activities. This commercial diplomacy is centered on a series of events to promote and facilitate international business. The main actors in commercial diplomacy range from the high level of the head of state, prime minister, minister or member of parliament, to the ambassador and the lower level of a special diplomatic envoy, usually, this commercial diplomacy is often used by state leaders in their visits to other countries.

Trade Diplomacy is diplomacy or negotiations carried out in the context of bilateral or multilateral relations in trade agreements, for example, such as the RIThailand export-import trade in rice, or trade affairs conducted at the WTO. Other examples include restrictions on imported meat by President Joko Widodo. Financial Diplomacy, is diplomacy played by the International Monetary Fund (IMF). For example, the IMF assists countries that are affected by the crisis. For example, 
Indonesia, in 1998, borrowed money from the IMF. These three diplomacies included in the economic approach in economic diplomacy. Both trade diplomacy and commercial diplomacy and financial diplomacy have the same goals, namely, economic goals. Still, the actors who play a role are political actors, the tools used are politics, and the goals to be achieved are economical.

Inducements are policies that affect a country. There are incentives given so that the country's plans change, so persuading a country to change its country's policies, by providing something that is needed by the state. That can get seen when the IMF lends money to Indonesia. By giving money to borrow to Indonesia, the IMF ordered Indonesia to change its system of government to a more democratic republic.

Negative Sanction is a tool of political trade, especially most often imposed by the United Nations (UN) and the European Union (EU). The main objective of all UN sanctions and embargoes, as stated in the UN Charter, is to implement the decision of the Security Council, namely to maintain or restore international peace and security. Also, other goals are usually to change the behavior of the target country's regime, individuals, or groups in a direction that will improve the situation in that country. Inducement and Negative Sanctions included in the Power Play End approach in economic diplomacy. The objectives to be achieved from the use of Inducement and Negative Sanction are political, but the tools or tools used are economics.

In addition to the opinion expressed by Peter AG Van Bergeijk, there are also other opinions expressed by Kishan S. Rana (an expert in economic diplomacy) regarding economic diplomacy. Namely, diplomacy is a process in which a country resolves its problems with other countries to maximize state income and gains through economic activities including trade, investment, and forms of exchange that are economically beneficial, both bilaterally, regionally and multilaterally, each of which is important ((Rana 2007, 204). Researchers argue that the concepts of diplomacy in Bergeijk and Kishan S. Rana are mutually in particular in the case of economic diplomacy were not only export-import, investment, aid, free trade agreements, but also other forms such as tourism and education.

Like diplomacy in general, economic diplomacy is a component of foreign policy - that is, a country's international activities. Foreign policy determines the goals and objectives of economic diplomacy, which in turn must reflect all events, forms, objectives, and methods used to realize these foreign policies. Barangay stated that economic diplomacy is a critical factor in the economy in its efforts to achieve foreign policy objectives (Baranay 2009, 3). The essence of economic diplomacy itself is to decide, carry out, and direct financial and political relations. In commercial negotiations, political factors are also therein. But sometimes economic considerations are not the same as political considerations, sometimes in line sometimes not. Therefore, the country must consider it well.

\section{Research Method}

The research methodology is a scientific way to obtain data with specific goals and uses. For this reason, researchers use qualitative research methodologies. Qualitative research methods are research procedures that produce descriptive data in the form of written or oral words from people and observable behavior (Moleong 2004, 25). The qualitative research methodology that researchers use for this research has a design in the process of its implementation. The initial step is identifying and selecting 
the problem to be studied, formulating the problem, conducting a literature review, making assumptions and hypotheses, then determining primary and secondary data collection, conducting data analysis, then ending with concluding.

In this study, researchers used qualitative research with descriptive analysis methods. With this method, the researcher tries to describe and provide an explanation following the facts that exist about the dynamics of Indonesia's relations with Australia that occurred during 2014-2016, and elaborate on economic diplomacy pursued by the two countries. For data collection techniques used in this study, researchers used to interview and document techniques.

Data can get categorized into two types, namely primary data and secondary data. Primary data is data that directly given to data collectors, and secondary data is data that is not directly given to data collectors, for example, through other people or documents (Sugiyono 2009, 224). Data and information that will get used in this study are primary data and secondary data from various sources that can get accounted for that. Primary data obtained from interviews conducted with Ms. Emilia Hartuty Elisa, Director General of the Asia Pacific and Africa Ministry of Foreign Affairs of the Republic of Indonesia, on Wednesday, May 24, 2017 (see appendix 1). Whereas secondary data obtained from related institutions, literature, books, magazines, documents, journals, newspapers, and information accessed from the internet, the sites of shareholders involved, the main places that will get made resources. Considering the diversity of sources of information that can get obtained, the selection and selection of sources that are considered most relevant to the purpose of the study conducted. Data is processed to produce a series of answers to research problems.

The data analysis technique that the researchers will use is a qualitative data analysis technique, i.e., the data obtained from various literature will get collected and clarified, and then the problem is explained and analyzed based on the facts available and compiled into writing. In processing data, researchers try to interpret the events, situations related to the actions and actions of actors. The collection of information that was initially random or unorganized was then compiled based on the needs of the analysis, then formulated into a series of descriptions obtained through the interpretation of several existing information. In the process of the study, the researchers hope to be able to describe and analyze the role of economic diplomacy in the dynamics of Indonesia's relations with Australia in the era of President Joko Widodo's administration in 2014-2016.

\section{Discussion and Result}

\subsection{Overview Relations between Indonesia and Australia}

Indonesia crossed by the equator, between the Asia continent and Australia also between the Pacific Ocean and the Indian Ocean. Indonesia is the largest archipelago in the world, also known as the Archipelago. Indonesia is among the most populous countries in the world (bps.go.id, accessed on 21 May 2017). Malaysia borders Indonesia on the island of Borneo with Papua New Guinea on the island of Papua and with Timor Leste on the island of Timor. Other neighboring countries are Australia, Singapore, the Philippines, and the union territory of the Andaman and Nicobar Islands in India.

Australia is the smallest continent in the world. Australia is often referred to as a 
continent because only one country in the world covers an entire continent. This continent located in the south of the Indonesian Archipelago. Australia is a rich country in natural resources, isolated, sparsely populated, and heavily dependent on trade and access in distant international markets. Since the colonies, Australia has been a supplier of mining materials, agricultural products, and industrial goods to the UK market.

Conversely, Australia also received capital outflow from Western European countries, especially Britain. Bilateral relations between Indonesia and Australia classified as unique relations; on the one hand, it promises various opportunities for cooperation, but on the other hand, it is also full of multiple challenges. A geographical location that is very close is what causes the relationship between the two countries is unique, where the Australian people prefer to take a vacation to spend their money in Indonesia, Bali. The Indian Ocean only separates the geographical areas of Indonesia and Australia, so it is not surprising that the relations between the two countries are so close.

It can get said that bilateral relations are a top priority in Indonesian and Australian foreign policy. Moreover, it can get seen from the similarity of perceptions in advancing the Pacific region and followed by the formation of the Australia Indonesia Development Area (AIDA) at a ministerial-level meeting (Ministerial Forum) on 2425 October 1996. Although the diplomatic relations between Indonesia and Australia had stretched after the release of East Timor from the unitary territory Indonesia in 1999, both countries can overcome these problems diplomatically.

The relationship between Indonesia and Australia has a reasonably long history since the days of Indonesia's independence struggle. Australia is one of the first countries in the world to recognize Indonesia's right to independence. During its development, bilateral relations between Indonesia and Australia experienced ups and downs. That happens because of the differences that exist between the two countries, among others, disputes related to the political system, social, economic, and cultural conditions.

The condition of bilateral relations between Indonesia and Australia has fluctuated from time to time. According to Collin Brown, an Indonesian expert in Australia said that the relationship between Indonesia and Australia was like a roller coaster. Australia was once Indonesia's representative at the Three Nations Commission at the United Nations (UN) to discuss the official recognition of the United Nations against the Republic of Indonesia in 1949. Relations between the two countries then experienced ups and downs, starting from the cases of East Timor, Papua, Illegal Fishing, terrorism, human smuggling, and the issue of trafficking of illegal drugs with all legal processes. Above all, the East Timor case considered to have incited a deep wound for relations between the two countries, especially Indonesia. Relations between the two countries have a long history. In its journey, relations between Indonesia and Australia are inseparable from conflict.

The fluctuations in bilateral relations between Indonesia and Australia caused by differences between the two countries, which are related to culture, the level of development progress, and political orientation, which result in different priority interests. There are at least three issues that shape the Australian public's perception of Indonesia, namely problems of defense and military, human rights, and Indonesia's violent image (Siboro 1989, 28). For Indonesia, Australia is considered necessary in addition to its role in the history of Indonesia's independence as well as political, social, economic, educational, and cultural connectivity. Indonesia is currently the largest 
recipient of Australia's aid program in the 2009/2010 budget year, with an estimated 452.5 million US \$. The value of trade in goods and services between the two countries reached US\$ 10.3 billion, with two-way investment reaching 4.5 billion US $\$$. Meanwhile, around 400 Australian companies are operating in Indonesia, covering the mining and energy, construction, financial, and food industries sectors (dfat.gov.au. accessed 21 May 2017).

\subsection{Dynamics of relations between Indonesia and Australia}

It is exciting to analyze the reasons for Indonesia and Australia, which are geographically very close and have high reciprocity interests, have a compassionate relationship, and are often ups and downs. In geopolitical theory, neighboring countries generally have many similarities, including ethnicity, culture, religion, and historical experience. That then becomes a factor of integration of two countries or regional integration; the more similarities, the easier the united states. However, this does not seem to apply to Indonesia-Australia relations. The two countries have significant differences in almost all fields. These contrasting differences have made it difficult for both to communicate with each other and understand each other's needs and interests in various areas. Even so, both of them realize that they need each other.

The event that records the dynamics of the bilateral relationship between Australia and Indonesia was the disintegration of East Timor in 1999. This event gave rise to a paradoxical situation (conflicting truth), where Australia felt that it was supporting the restoration of peace in East Timor through its involvement in the International Force on East Timor (INTERFET). Still, Indonesia considers Australia not neutral because it tends to favor non-integration groups who want East Timor's independence (Makarim 2003, 55).

Although the Australian policy has influenced the emergence of the Indonesian government's negative perceptions of Australia, the country continues to seek cooperation with Indonesia, given the psycho-historical considerations where Indonesia's expansive actions in the past were deemed capable of threatening Australia's sovereignty. Australia and Indonesia recognize the importance of improving bilateral relations and enjoy cooperation in various fields. They get confirmed by the signing of the Comprehensive Partnership Declaration in 2005, mostly an effort to increase participation in different areas.

Nearly a year ago, the decision to grant asylum to 42 Papuans by the Australian government seemed contradictory and ignored the issue of separatism in Papua. Australia-Indonesia diplomatic relations disrupted again. Regarding the asylum case, Australia and Indonesia agreed to conduct a review of the cooperation framework, which was then followed by the signing of the Agreement on Framework for Security Cooperation, better known as the Lombok Treaty in 2006 and more effectively binding the next two years in 2008. The Lombok Treaty became an umbrella legal cooperation in the Australia-Indonesia defense-security sector (Bakti 1996, 298).

In June 2011, Australia unilaterally stopped cattle exports to Indonesia due to concerns about the practice of slaughter and torture of livestock at slaughterhouses in Indonesia. While in Indonesia, the price of beef has begun to surge, it also has implications for macro-economic stability and makes consumers disappointed. The practice of slaughter can hardly be changed overnight, and research needed on where the problem is and how it can get overcome. Indonesia is monitoring and repairing 
slaughterhouses but is in no hurry to continue importing Australian cattle, while the needs of Australian exporters are turning to China (bbc.news.co.id accessed June 1, 2017).

In 2012 the bilateral relations between Australia and Indonesia continued to show momentum. Australia's position in responding to the issue of the separatist movement of the Free Papua Movement (OPM), which re-emerged in 2012, has led to negative perceptions in the Indonesian camp. One Australian MP said that Papua had the right to be allowed to hold a referendum again. Indonesia questions the consistency of Australia, which previously recognized Papua as an integral part of the Unitary State of the Republic of Indonesia (NKRI) in 1962.

2013, the problem of illegal immigrants and the policy of overflowing their arrival in Australia get seen by Indonesia as a sovereign challenge. Australia applies a law to send back immigrant ships arriving in the country. This rule makes Indonesia flooded with immigrants. Unresolved, the Indonesian government again felt disadvantaged by Australia related to the espionage scandal. In November 2013, it got revealed that President SBY's cell phone tapping and several high-ranking Indonesian officials tapped by the Australian intelligence agency (www.cnnindonesia.com accessed June 20, 2017).

When in 2014, a presidential election held in Indonesia. Australia became like a whip of nationalist sentiment. In Canberra, there is concern that whoever becomes the new president will not tend to establish better relations with Australia. Former commander Prabowo Subianto is the Kopassus commander in East Timor. At the same time, Joko Widodo has no foreign relations experience and has no relationship with Australia other than his eldest son, who graduated from the University of Technology Sydney (UTS). Jokowi won the election and took office in October 2014, ushering in a period of temporary diplomatic relations between the two countries. In April 2015, relations were cold to freeze. The President's determination to move forward with the execution of convicted Australian drug traffickers Andrew Chan and Myuran Sukumaran, who opposed media madness in Australia and formal statements by the Australian government, led to the withdrawal of the Australian ambassador.

The Indonesian government refused to provide leniency on the sentences of two convicted persons. Australians protested the Indonesian court's decision and condemned the death sentence in Indonesia. The attitude of the Australian people is very contrary to Australia's insistence on Indonesia to quickly sentence the perpetrators of the Bali Bombing I. Even Prime Tony Abbot made a speech and in it brought up the humanitarian assistance that Australia had given to Indonesia during the tsunami in Aceh. Australia's attitude continues with the threat of reducing scholarships for Indonesian students who will go to school in Australia. Another problem hampering relations between Indonesia and Australia regarding security is the problem of boat people, namely refugees from conflict areas such as Iraq, Iran, Afghanistan, Vietnam, Sri Lanka, and Myanmar. They come through Indonesian waters to Australia to seek asylum. Prime Minister Tony Abbot rejects the presence of boat people and drives them out of Australia to protect their borders and internal security. Indonesia, as a neighbor country that direct border with Australia, affected must accept boat people for humanitarian reasons.

Australia's attitude complicates its relationship with Indonesia. Moreover, evidence was found of bribery by Australian officials to boat crews to bring boat people back to Indonesia. Indonesian officials discovered this evidence on Rote Island in May 
2015, who arrested 65 boatmen from Bangladesh, Sri Lanka, and Myanmar who were going to sail to New Zealand. (International.sindonews.com, accessed May 18, 2017). The Abbott administration did not provide an answer that satisfied the Indonesian public. Australia's concern about its border security threats considered to have violated the principles of harmonious diplomacy between neighboring countries and human rights laws that have become universal since the PPB introduced the International Human Rights Convention on 10 December 1948. During Abbot's leadership, before Malcolm Turnbull replaced him in September 2015, the expulsion of boat people continued with the sending of uncrewed aircraft or drones to monitor immigrants coming from Indonesia.

There is a guaranteed backlog of unresolved issues in Australia and Indonesia relations, where ships, beef, and the death penalty have been the most controversial. But in most cases, including this, there are shared interests. Australia insisted on integrity from its borders, moved its naval forces to the southern edge of Indonesia with a highly classified operation (Operation Sovereign Borders), and it seemed surprising that Indonesia then held to its sovereignty. With enormous financial and diplomatic costs, the Australian government has stopped the influx of asylum seekers, but thousands of people still stranded in Indonesia cannot move forward or backward. Indonesia does not have the means to monitor its entire sea and land boundaries so that problems in Indonesia are not easily encountered (kompas.com, accessed on 12 June 2017).

But a week after PM Turnbull visits Jakarta, the Government of Indonesia announced a moratorium on further executions. That did not come from Jokowi himself but from the most powerful person in the Indonesian cabinet, the Coordinating Minister for Politics, Law, and Security, former general Luhut Pandjaitan, who had just returned from discussions in Canberra. He acknowledged that the issue had been discussed in Australia but stressed that Australia had promised not to interfere in domestic matters for Indonesia. Quiet diplomacy with respect on both sides finally brings what failed, and unpleasant interventions have been achieved (http://www.e-ir.info).

\subsection{The economy as an Important Factor in Maintaining Stability of Relations between Indonesia and Australia}

The state is similar to humans. No human can live alone without help from others. Likewise, the state, no country can survive without cooperation with other countries. The needs of a country's population increase with the increasing population. While the ability to procure products to meet these needs is increasingly limited, as a result, the products needed cannot get produced entirely domestically, either because of the availability of scarce natural resources or because of the technological capabilities and low quality of human resources.

For this reason, cooperation is needed, especially in the economic field. Developing countries need machinery and equipment, capital, and technology from developed countries. Likewise, developed countries need raw materials and natural resources from developing countries. The economy is an essential factor because every state must carry out economic activities to meet their needs. Indonesia and Australia have undergone bilateral relations in the commercial sector, including in trade, tourism, and investment relations.

- Trading

Each country cannot stand alone without cooperation with other countries, 
including Indonesia and Australia. One of the collaborations is in the field of trade. Participation in the trade sector arises because differences exist between one country and another, such as differences in production factors, differences in the level of technology, and differences in the efficiency of the utilization of these factors (Cticchley $1995,12)$. Trade activities carried out by one country with another country are exportimport. The data shows that there are 13 principal trading partners of Indonesia, the countries that traded with Indonesia with the most substantial dollar value during 2016, also showed a percentage of total Indonesian exports in each state. Australia is among the 13 major trading partners of Indonesia and ranks 12th with a value of US \$ 3.2 billion or around $2.2 \%$ of Indonesia's total exports.

Australia's primary export commodities in 2015-2016 include wheat, live animals, sugar syrup and honey, and petroleum. While Australia's main imports from Indonesia are petroleum, machinery, and unique parts, wood, and gold, it can get seen that Australia imports raw materials from Indonesia, and the most are crude oil because Indonesia is one of the oil-producing countries. Australia also exports the most wheat, followed by live animals such as cows, where Indonesia urgently needs cattle imports from Australia because the supply of cattle in Indonesia cannot meet the needs of all the people of Indonesia. From 2013 to 2016, the trade balance shows a declining number. 2016 was Indonesia's lowest export value for the past ten years. That makes Indonesia and Australia feel the need to increase cooperation in the trade sector for the benefit of both parties even more.

- Investment

The next sector, investment, based on BKPM data, in the fourth quarter of 2016, the realization of Australian investment in Indonesia ranked 19th with a value of US \$ 29.0 million for 272 projects. While cumulatively, investment realization from January to December 2016 reached US\$ 174.7 million for 813 projects. If seen from the investment trends of several partner countries, from 2011 to 2016, the realization of Australian investment was the lowest of 0.5 percent in 2011 and the highest figure was 2.8 percent in 2012, while in 2016 the investment trend was at 0.6 percent (bkpm.go.id accessed on May 21, 2017).

In addition to the investment, Australia's desire to establish cooperation in the tourism sector will add to the country's investment figures in Indonesia. That way, trade relations between Indonesia and Australia are not only dominated by imports of meat, but more than that, various cooperation in the mining and energy sectors can also get explored. Significant areas between the two countries can get increased to produce a mutually beneficial trade balance.

- Tourism

The tourism sector is one of the supports of the economy because tourists coming to a country will undoubtedly increase the country's foreign exchange. Indonesia is a country that has panoramas and beautiful and exciting tourist attractions. That is why many foreign tourists who come to vacation in Indonesia each year, including the nearest state of Indonesia, namely Australia. Australia is one of the most visited countries in Indonesia. In the tourism sector, the number of Australian tourist arrivals to Indonesia from 2007 to 2016 increased significantly. From initially, only 314,483 tourists grew to $1,198,429$ tourists in 2016. Of course, this increase in the tourism sector contributed to Indonesia's economic benefits through foreign exchange coming through tourism. The tourists from Australia visited Bali a lot and became a profitable foreign exchange earner for Indonesia. Every summer holiday season and the 
end of the year, Australian tourists always visit Bali. Australian tourists like the area of Bali because of the situation and the view that is different from the country, this has the advantage of both parties, Australia enjoys the beautiful panorama of Bali, and Indonesia gets foreign exchange.

\section{- Education}

Education is also one of the economic supports, for example, with international students studying in a country, this will help increase the country's foreign exchange through spending money on living expenses while the student is studying in that country. Studying abroad can also improve the quality of human resources, which will undoubtedly be very useful for the country. Many Indonesian students continue their tertiary education elsewhere. The number of Indonesian students pursuing tertiary education abroad in 2015 totaled 84,057 students spread across 17 countries, namely Singapore, Australia, Malaysia, the People's Republic of China, America, Egypt, Germany, Japan, the Philippines, the Netherlands, the United Kingdom, New Zealand, India, Saudi Arabia, France, South Korea, and Thailand. The country that was most indemand by Indonesian students to continue their tertiary education in 2015 was Singapore, with 21,043 students and maintained by Australia with 16,545 students. Australia is the second leading country favored by Indonesian students due to the quality of Australia's international education system and a variety of courses that not found anywhere else.

Although there have been ups and downs of relations between Indonesia and Australia, even sometimes accompanied by the return of the Ambassador to each country of origin, Indonesia and Australia still try to maintain economic relations between the two countries. Economic factors are essential factors in maintaining the stability of relations between Indonesia and Australia. Tourism, education, investment, trade, and other sectors, if pulled in their entirety, will undoubtedly be related to the economy. For example, the tourism sector, tourists who enter Indonesia, namely to Bali, of course, increase foreign exchange and also promote Indonesian tourism. The education sector, with the large number of Indonesian students studying in Australia, of course, grows Indonesia's Human Resources (HR), and the trade sector that gets linked to exports and imports certainly makes the two countries unable to break away from each other. Indonesia's economic relations with Australia are maintained even though political affairs experience obstacles and tensions. The dynamics of Indonesia's ties with Australia in the political field, also having to break diplomatic relations by returning their respective ambassadors, did not necessarily make Indonesia and Australia sever economic links as well. That is due to the consideration of the importance of two countries to each other in the financial field.

Australia, which is the most remote and isolated continent, naturally needs Indonesia as a strategic trade channel. If Australia breaks economic relations with Indonesia, the Australian economy will die because products from other countries cannot enter the country without going through Indonesia. The combination of a population of 261.1 million in 2016 (www.worldbank.org accessed on 12 May 2017), which is ten times that of Australia's population, territorial area, economic potential, and political power possessed by Indonesia makes it a country that has most influential in Southeast Asia. Indonesia is the founder and cornerstone of ASEAN. Australia considers that Indonesia has an essential role in the Southeast Asian region, and also plays a critical role in ASEAN.

On the other hand, Indonesia needs wheat and cattle from Australia because 
Indonesian production is insufficient for the needs of all Indonesian people from Sabang to Merauke, so exports from Australia are required to support it. Likewise, Australia is the second-largest foreign exchange earner to Indonesia because tourists from Australia who go to Bali are huge. If Indonesia's economic cooperation with Australia increased again, it would benefit both countries because its proximity will undoubtedly save costs compared to other countries. These are the things that make the two countries still pay attention to economic relations because the two countries feel essential to each other.

Both Indonesia and Australia are currently working on increasing trade relations between the two countries. Australia's commitment demonstrated by conducting trade mission visits to Indonesia. On 21 September 2015, the Australian Minister of Trade and Investment, Andrew Robb, visited to promote the Indonesia-Australia week, which was held on 17-20 November 2015. In this visit, the Australian Minister of Trade and Investment brought around 200 Australian business people (www.cnnindonesia.com accessed on 18 June 2017). This visit also needs to be utilized by Indonesia to introduce and promote Indonesian products. Efforts to improve economic relations can get made through economic diplomacy.

\subsection{Indonesia's Economic Diplomacy in the Dynamics of Indonesia's relations with Australia in the era of President Joko Widodo's administration (2014-2016)}

Economic diplomacy has now become the focus of Indonesia's interests as an effort to develop the economy and regional stability in the future. Increasing economic diplomacy has become one of Indonesia's foreign policy priorities for 2014-2019. That gets formulated following the vision and mission of the President outlined in Nawa Cita, Trisakti, the 2015-2019 National Medium-Term Development Plan (RPJMN), and the Ministry of Foreign Affairs (Ministry of Foreign Affairs) 2015-2019 Strategic Plan (Rienstra) 2015-2019 (Emilia Hartuty Elisa in an interview, attachment 1).

The structure and operation of the international economic system are more determined by the formation and implementation of the global political system, where production, distribution, and consumption throughout modern history influenced by diplomacy and strategy factors. That means that economic diplomacy is not only used for industrial purposes but political and strategic purposes (Rudy 1992, 102).

Although it seems that political considerations emerge as the primary concern of a country's diplomacy, economic factors are also not less important. Capitalist countries continue to be busy in finding a foothold in new markets and, at the same time trying hard to secure their economic interests in areas where they have been able to maintain their presence by eliminating competition. With the birth of the free trade system and its impact on the emphasis of the national economy, developed and underdeveloped countries have come across the fact that trade and finance can get used as the main tools of national policy. As a result, the achievement of economic gains has become an essential objective of diplomacy (Roy S., 1991, p. 10).

Physically, Indonesia is a vast country with various advantages, not only natural resources and market potential, because of the large population alone. Indonesia's geographical position, which lies between two continents and two oceans, has a unique advantage that many other countries do not have. Indonesia's territorial sea and the air is a unique asset that can get used as a "training power" to be able to obtain a "profitable position" in economic diplomacy. Like for example by the Ministry of Maritime Affairs and Fisheries today, which enforces strict action on foreign fishers who take fish in 
Indonesia's territorial sea territory, has made many countries experience shortages of fish supply.

The geographical and physical condition of Indonesia has a significant role in economic diplomacy because this region of Indonesia can affect the distribution of products and services for commercial activities.

In the era of globalization, which is the process of integration between countries to facilitate transactions in various fields, the role of economic diplomacy is increasingly essential to maximize the acquisition of things that are needed.

In Indonesia, President Joko Widodo gave directions to several Indonesian Ambassadors abroad. The President wants economic diplomacy to be the main focus. The Ministry of Foreign Affairs is focusing on increasing economic diplomacy through Indonesian representatives abroad (Emilia Hartuty Elisa in an interview, appendix 1). The Ministry of Foreign Affairs has also formed an Economic Diplomacy Task Force related to four sectors: trade, tourism, investment, and development cooperation. Indonesia's representation abroad is significant in its position and role as the spearhead in the economic diplomacy process. Of course, members and leaders of these representatives required to increase their knowledge, abilities, expertise, and skills, not only in the art of diplomacy alone, but also in the culture of the nation and country where they located, the culture of the Indonesian government, and other matters relating to this. That is very important to instill confidence in the diplomatic process that will get carried out. Based on article 28 of Law no. 37 of 1999 concerning Foreign Relations (kemlu.go.id accessed on 3 June 2017), the Indonesian Ministry of Foreign Affairs is mandated to carry out the task of coordinating Indonesia's foreign relations and Indonesian foreign policy. Considering that economic diplomacy is an essential part of Indonesia's foreign policy, the Minister of Foreign Affairs remains the holder of full responsibility in carrying out economic diplomacy. Although in practice, economic diplomacy is carried out by various ministries and other government agencies such as the Ministry of Trade, the Ministry of Tourism, and the Investment Coordinating Board (BKPM), the Ministry of Foreign Affairs is responsible for establishing good relations between Indonesia and other countries. It plays a crucial role in the negotiation process to achieve economic and investment cooperation agreement. It meant to ensure the unity of attitudes and actions in the administration of foreign relations and the implementation of foreign policy (Kemlu, 2015).

Furthermore, the President of the Republic of Indonesia, on several occasions, also emphasized that the implementation of Indonesia's foreign policy also focused on economic diplomacy. He stated that Indonesian ambassadors overseas acted appropriately as "salesmen" in promoting Indonesia's economic potential. The application of economic diplomacy as a policy priority outside of Indonesia's horror shows a balanced emphasis between political and economic aspects so that they can run between political and economic issues so that they can go hand in hand and support one another. Political elements resulting from the implementation of foreign policy to create good relations between countries can get utilized to gain economic benefits, among others, through increased exports of goods/services or prospective market expansion.

At the bilateral level, Indonesia's economic diplomacy carried out to encourage the reduction of various obstacles in trade with primary markets and the opening of prospective markets and to improve relations between the two countries (Ministry of Trade, 2014). During this time, the potential for foreign markets for Indonesian products is quite vast but has not worked on nationally. The prospective market, which is 
Indonesia's trade destination, is also still tiny.

The table above shows the eleven major export destinations of Indonesia to other countries and also the eleven states that import to Indonesia. The United States is the first country to be Indonesia's export destination, and China is the first country to import into Indonesia. Australia, which is one of Indonesia's closest neighbors, ranks eleventh as Indonesia's export destination country and ranks eighth as a country that imports to Indonesia. The maximum implementation of economic diplomacy by Indonesia will increase the value of export-import.

At the global level, Indonesia, as a member of the G-20, plays an active role in efforts to deal with the global economic crisis and encourage reforms in global economic governance. Therefore, the position as a member of the G-20 needs to get utilized as well as possible. Indonesia's Economic Diplomacy directed to strengthen the interests of the national economy in the next five years aimed at supporting the growth of Indonesia's economic quality or "growth with equity." This growth will get carried out through trade investment strategies, increased competitiveness, financial inclusion, and productivity. Indonesia's diplomacy to support quality and balanced growth is in line with the interests of developing countries.

From the data obtained, the twelve major Australian export destinations to other countries and also the twelve major countries that import to Australia. From this information, China is the first ranked country to be the destination of Australian exports and even the first ranked country to import into Australia. Indonesia, which is one of Australia's closest neighbors, is ranked tenth as Australia's export destination country and is ranked twelfth as a country that imports to Australia.

The dynamics of relations between Indonesia and Australia that have fluctuated so far have indeed created various challenges, but they have not made Indonesia and Australia cut off ties. Although Indonesia was disappointed with Australia's actions regarding the asylum case and Australia was also disappointed when the convicted case of the execution of Bali Nine get carried out, the two countries tried to continue to improve relations between the two.

Both countries consider each other necessary, especially in the economic field, which makes the two countries cannot get separated for a long time. Economic diplomacy is one of the essential instruments in a country's foreign policy. In this context, international relations between countries can be the glue of political ties. Then it can be said that economic links can play a role as an influential factor in political relationships. The concept of economic diplomacy from Peter AG Van Bergeijk is not enough for the true meaning of economic diplomacy. The Kishan S. Rana concept complements it in terms of the implementation of economic diplomacy were not only export-import, investment, aid, free trade agreements, but also other forms such as tourism and education. Trade, finance, tourism, and education are essential parts that work together in the implementation of economic diplomacy. By conducting economic diplomacy in the preceding, improvements in various sectors will also increase.

The implementation of economic diplomacy between Indonesia and Australia is more directed towards one form of economic diplomacy, namely Trade Diplomacy. In its concept, Trade diplomacy realized through the implementation of bilateral Free Trade Agreements, multilateral WTO, Anti-Dumping Tax rate, Export / Import License, Export / Import quota, investment, and trade barriers. Free Trade Agreement is a free trade agreement between a country and another country. The establishment of FTAs is a result of trade liberalization, which cannot be avoided by all countries as members of 
the international community (www.kemenkeu.go.id accessed on June 23, 2017). FTAs can be formed bilaterally, for example, Indonesia, with Australia in IA-CEPA negotiations.

It can get said that with an FTA, a country will benefit both economically and non-economically. Economic benefits to be obtained include economic growth, increasing market access, and promoting trade and direct investment. In contrast, the benefits outside the economy are social and political stability and deepening mutual understanding between countries. In the investment sector, in President Jokowi's speech at the APEC Summit in November 2004, it was clearly stated that Indonesia opened up opportunities for large amounts of investment, especially for infrastructure development and connectivity in the next five years. President Jokowi said that Indonesia would be open for investment in 24 seaport and in-depth seaport development projects, railway track, and railway network that connects the largest islands in Indonesia. Power plants for manufacturing and industrial areas and the manufacture of public transportation in several major cities in Indonesia and the construction of sea tolls within the framework of maritime diplomacy.

As one of the 20 largest economies in the world that incorporated in the Group of 20 (G-20), Indonesia is a country that has an open Pancasila economy. This economic openness must be accompanied by economic competitiveness so that Indonesia can become a competitive country. Therefore, since the beginning of President Joko Widodo's administration in 2014, Indonesia's economic diplomacy has been focused more on promoting exports, promoting tourism, and increasing trade, tourism, and investment (TTI-trade, tourism, investment). TTI-trade, tourism, finance is an economic policy package launched by the government relating to three main economic activities. Namely trade, tourism, and investment, which expected to make a positive contribution to efforts to achieve economic growth of 5.7 percent in 2017 (kemenkeu.go.id accessed on June 16, 2017).

Indonesia's economic diplomacy also directed at strengthening bilateral and regional economic cooperation systems, including intensifying negotiations on the Comprehensive Economic Partnership Agreement (CEPA) with several countries and regions, including Australia (IA-CEPA). Trade diplomacy, as part of economic diplomacy carried out through the Free Trade Agreement and bilateral relations, is realized by the IACEPA, which is currently in the process of negotiating the two countries. The IA-CEPA expected to be a lucrative cooperation opportunity for Indonesia and Australia as the closest neighbors geographically.

\subsection{Indonesia-Australia Comprehensive Economic Partnership Agreement (IA- CEPA)}

Economic relations between Indonesia and Australia are indeed crucial for the two countries. Still, the economic value is not maximal when compared to other countries that not located close to each other. Two neighboring countries whose territories are very close together should have the opportunity to obtain a strong economy and complement each other. As is known, Indonesia ranks only ten Australian trade partners at US\$ $3.55(1.9 \%)$, compared to New Zealand, which is the eighth trade partner of US \$ $4.36(2.3 \%)$ and is the third-largest investment destination (US\$ 170.4 billion). Likewise, with Malaysia, which only has about one-tenth of the population and less than half of Indonesia's Gross Domestic Product (GDP), became Australia's sixth- 
largest trading partner of US \$ $4.72(2.5 \%)$.

That has also encouraged the formation of bilateral FTAs between Indonesia and Australia as an excellent way to foster trade and investment relations. In July 2007, the Governments of Indonesia and Australia agreed to conduct a joint feasibility study to assess the benefits of bilateral FTAs. Held in July 2009, the study found that, the FTA provided complementarity for the economies of the two countries, including goods, services, and investment. It can increase trade and investment, strengthen bilateral relations and regional economic integration, has a positive impact on the agriculture and manufacturing sectors that are important for Australia and Indonesia, and provides significant opportunities for businesses and exporters. That shows to achieve profits, all tariffs, non-tariff barriers, and all obstacles to bilateral trade services must get removed because this can be a significant obstacle to Australian investment in Indonesia and vice versa. Based on the findings of the feasibility study, finally, the negotiations for the establishment of a bilateral FTA of the Indonesia Australia Comprehensive Economic Partnership Agreement (IA-CEPA), began in September 2012 when Indonesia was under the administration of President Susilo Bambang Yudhoyono. IA-CEPA negotiations under the administration of President SBY have not been optimal and have even been inactive or no longer carried out. During the leadership of President Joko Widodo, the reactivation of the IA-CEPA negotiations began to re-emerge.

In a Joint Statement on reactivating the IA-CEPA negotiations in Canberra, 16 March 2016, the Indonesian Minister of Trade and the Australian Minister of Trade agreed to revive talks on the IA-CEPA. And believe that a successful agreement would become a new platform towards modern and dynamic economic cooperation, which reflects the strong ties between the two countries. This initiative determines the determination of the two governments to create conditions that must be fostered to expand two-way trade and investment and will maximize the potential for economic relations between the two countries (see appendix 3 ).

The reactivation of the Indonesia-Australia Comprehensive Economic Partnership Agreement (IA-CEPA) negotiations received full support from employers. Six main points become essential points in the discussion of trade negotiations, which targeted to be completed by the middle of 2017. The six sectors are higher education, health, mining, services, digital startups, and agriculture. These sectors have the potential to build closer and mutually beneficial relations. Key to the IA-CEPA negotiations is not just in the hands of the government; this success is also very dependent on the relationships between the business actors of both countries. To accommodate the proposals in the negotiation process, the entrepreneurs of the two countries formed a forum, namely the Indonesia-Australia Business Partnership Group (IA-BPG).

The IA-CEPA expected to be more comprehensive in its scope to include trade and services, investment, electronic commerce, trade competition policies, procurement of State goods, intellectual property rights, the environment, labor, and other relevant new things. IA-CEPA is part of trade diplomacy with the realization of bilateral FTAs between the two countries.

The trade agreement between Indonesia and Australia is not only limited to tariff reduction but also non-tariff factors. So far, the application of standards and quality of products coming into Australia is strict. The entry of investment and technology transfer through trade is also an essential point for Indonesia. During this time, Australia is mighty in the agriculture and animal husbandry industry. With this collaboration, the 
development of the agricultural sector in Indonesia will be better. The IA-BPG believes that close economic cooperation can get achieved between the two countries by removing trade barriers and facilitating regulation. In the technical discussion of the negotiations, the sectors that will target reducing tariffs are still in the discussion stage. Some of them are partnerships in the development of the Indonesian meat and livestock sector, financial services collaboration, and collaboration in the creative industries. In the Indonesia-Australia Partnership on Food Security in the Red Meat and Cattle Sector, there is an initiative created to help prevent the recurrence of tensions and disruptions in bilateral trade related to the export-import of live cattle.

From Indonesia, there is a complement between Australia and Indonesia in the trade of goods. Indonesia can provide primary and manufacturing products (such as crude palm oil, cocoa bean products, paper and paper board, rubber, etc.). At the same time, Australia will increase in size for meat and dairy products, wheat products, and the service sector (such as business travel services. Also, Indonesia can expect a bona fide from IA-CEPA with the presence of Australian investors in mining, agriculture, animal husbandry in cooperation, and program development capacity in the areas of standard regulations, health, and intellectual property rights (see appendix 4).

The two countries know that to achieve mutual benefits, the IA-CEPA will be comprehensive as a whole. And not only aim to improve their economy but also to facilitate investment flows and goods services by lowering barriers and other tariffs behind investment restriction measures. Measures that have the effect of inhibiting or preventing more significant trade and investment and enhancing other technical cooperation in specific sectors get identified as the main obstacles to economic growth (see appendix 5).

Until last May 2017, IA-CEPA negotiations have taken place in seven rounds, which took place in Indonesia and Australia and will enter the eighth round. Rounds one through to the last series have discussed important agendas related to IA-CEPA comprehensive cooperation. The IA-CEPA negotiation meeting looks more intense and shows positive things, namely progress in each of the negotiations. Both countries are targeting that the IA-CEPA negotiations can get completed by the end of 2017 .

With the political dynamics between Indonesia and Australia that have been happening all this time, even having to break diplomatic relations by returning their respective ambassadors, does not necessarily make Indonesia and Australia cut off economic ties as well. Consideration of the importance of the two countries to each other in the economic field plays a part in it. Economic diplomacy carried out in the era of President Joko Widodo's administration supported the commitment or agreement to maintain the stability of relations with each other through the IA-CEPA. A successful deal will be a new platform towards modern and dynamic economic cooperation that reflects the strong ties between the two countries.

\section{Conclusions and Recommendations}

The relationship between Indonesia and Australia has experienced ups and downs, like a roller coaster that goes up and down, sometimes warm and close but sometimes also cold and distant. The dynamics of relations between the two countries are influenced by case by case ranging from wiretapping cases committed by Australia to the death penalty of Australians by Indonesia. The relationship between Indonesia and Australia gets classified as a unique relationship; on the one hand, it promises 
various opportunities for cooperation, but on the other hand, it is also full of challenges. That is due to differences between the two countries, such as historical background, culture, ideology, and political orientation, which result in different priority interests as well.

The two countries have made efforts to transform various challenges and potential conflicts into an arena of cooperation that is beneficial to the two countries, which realized through the implementation of economic diplomacy. The economic factor is an essential factor for the two countries, which causes the two countries to be still connected even though the cases that have happened so far have hurt each other.

Economic relations between Indonesia and Australia are indeed crucial for both countries, but the value is not yet maximal when compared to other countries. Two neighboring countries whose territories are very close together should have the opportunity to obtain a stable and relatively economic economy that complements the two countries. As is known, Indonesia ranks only 10th of Australia's trade partners at US\$ 3.55 (1.9\%), compared to New Zealand, which is the 8th trade partner of US \$ 4.36 $(2.3 \%)$ and is the 3rd largest investment destination (US\$ 170.4 billion). Likewise, with Malaysia, which only has about one-tenth of the population and less than half of Indonesia's Gross Domestic Product (GDP), became Australia's 6th largest trading partner of US $\$ 4.72(2.5 \%)$.

For this reason, economic diplomacy plays a vital role in improving the economy and relations between Indonesia and Australia to be tighter and reduce tensions or conflicts between the two countries. Increasing economic diplomacy has become one of Indonesia's foreign policy priorities for 20142019. The role of Indonesia's Economic Diplomacy in the dynamics of Indonesia's relations with Australia in the administration of President Joko Widodo is significant. It will improve the sectors of both tourism (increased foreign exchange), economy (exports -imported increase, not deficit), education (quality of human resources increased, foreign exchange increased), investment (investment value increased), and others.

Trade diplomacy as part of economic diplomacy carried out through the Free Trade Agreement, and bilateral relations is realized by the IA-CEPA (IndonesiaAustralia Comprehensive Economic Partnership Agreement), which is currently still in the process of negotiations between the two countries. The IA-CEPA expected to be a lucrative cooperation opportunity for Indonesia and Australia as the closest neighbors geographically. Six main points become essential points in the discussion of trade negotiations, which targeted to be completed by the end of 2017. The six sectors are higher education, health, mining, services, digital startups, and agriculture. These sectors have the potential to build closer and mutually beneficial relations.

Economic diplomacy carried out in the era of President Joko Widodo's administration supported the commitment or agreement to maintain the stability of relations with each other through the IA-CEPA. A successful negotiation will be a new platform towards modern and dynamic economic cooperation that reflects the strong ties between the two countries.

Indonesia's policy in optimizing economic diplomacy is the right step, and Indonesia needs to conduct economic diplomacy with Australia to improve the condition of the two countries that are up and down so far. The IACEPA collaboration expected to strengthen Indonesia's relations with Australia and, at the same time, be an opportunity to maximize Indonesia's and Australia's economic and trade improvement. 
Improvements must be made to the industrial sector, product quality, human resources, etc. so that in the FTAs conducted, Indonesia can compete and not suffer losses. Still, it can fulfill its national interests and also regional stability, especially relations with Australia. 


\section{BIBLIOGRAPHY}

\section{Books}

Adil, Hilman. 1993. Hubungan Australia dengan Indonesia 1945-1962. Jakarta: Djambatan. Ary, Donald. 2004. Pengantar Penelitian dalam Pendidian. Yogyakarta: Pustaka Pelajar.

Azizah, N. 1992. Kerjasama Ekonomi Indonesia-Australia. Jakarta: Prospektif.

Baranay, Pavol. 2009. Modern Economic Diplomacy. Latvia: Publications of Diplomatic Economics.

Barston, R. P., 1997. Modern Diplomacy. Harlow: Pearson Education Limited. Bergeijk, P., 2007. Economic Diplomacy and Economic Security. Lisbon: ISCP.

Chauvel, Richard. 2005. Indonesia - Australia: Tantangan dan Kesempatan dalam Hubungan Politik Bilateral. Jakarta: Granit.

Cipto, Bambang. 2010. Hubungan Internasional di Asia Tenggara: Teropong Terhadap Dinamika, Realitas, dan Masa Depan. Yogyakarta: Pustaka Pelajar.

Cticchley, S. 1995. Hubungan Australia dengan Indonesia: Faktor Geografi, Politik, dan Strategi Kekuasaan. Jakarta: Penerbit UI.

Fitriani, Evi. 2012. Australia \& Negara-negara di Kepulauan Pasifik Selatan. Jakarta: Universitas Indonesia Press.

Hamid, Z. 1999. Sistem Politik Australia. Bandung: PT Remaja Rosdakarya.

Kementerian Luar Negeri. 2015. Penguatan

Diplomasi Ekonomi untuk Mendukung Pembangunan Kawasan Timur Indonesia. Jakarta: Pusat P2K2 Asia Pasifik dan Afrika, BPPK.

Makarim, Z. A. 2003. Hari-Hari Terakhir Timor Timur, Sebuah Kesaksian. Jakarta: PT. Sportif Media Informasindo.

Mankoff, J., 2009. Russian Foreign Policy: The Return of Great Power Politics. New York: Rowman \& Littlefield Publisher.

May, Rudi Teuku. 1992. Teori Etika dan Kebijakan Hubungan Internasional. Bandung: Angkasa.

Moleong, Lexy J. 2004. Metode Penelitian Kualitatif. Bandung: Remaja Rosdakarya. Moons, Selwyn. 2007. Economic Diplomacy and Economic Security. Lisbon: ISCHAL. Nazir, Moh. 2011. Metode Penelitian. Jakarta: Ghalia Indonesia.

Poesponegoro, M. D. 1993. Sejarah Nasional Indonesia. Jakarta: Balai Pustaka.

Rana, S. K., 2007. The New Economic Diplomacy: Decision Making and Negotiation in International Economic Relations. Hampshire: Ashgate Publishing.

Rudy, T. M. 1992. Teori Etika dan Kebijakan Hubungan Internasional. Bandung: Angkasa. Roy, S. L. 1991. Diplomasi. Jakarta: Rajawali Pers.

Siboro, J. 1989. Sejarah Australia. Jakarta: Depdikbud Dirjen Dikti PPLPTK.

Soebadio, Hadi. 2002. Keterlibatan Australia dalam Pemberontakan PRRI/Permesta. Jakarta: PT Gramedia Pustaka Utama.

Sugiyono. 2009. Metode Penelitian Kuantitatif, Kualitatif, R\&D. Jakarta: Alfabeta. Sukmadinata, Nana Syaodih. 2007. Metode Penelitian Pendidikan. Bandung: Remaja

Rosdakarya.

White Paper on Australia's Foreign and Trade Policy. 1997. Canberra: DFAT. 
Wolfe. 1986. Introduction to International Relations: Power and Justice. New Delhi: Prentice-Hall of India.

\section{Document}

Kementerian Perdagangan Republik Indonesia. Strategi Promosi Perdagangan Indonesia, 2014. Direktorat Kerjasama Regional, Direktorat Jenderal Kerjasama Perdagangan Internasional.

\section{Journal}

Djumala, Darmansjah. 2014. Membumikan Diplomasi Ekonomi: Tantangan dan Kebijakan Luar Negeri Era Jokowi-JK. Jurnal Diplomasi Volume 6, Nomor 3, November. Hal. 20-28.

\section{Internet}

academia.edu cnnindonesia.com dfat.gov.au ditjenkpi.kemendag. go.id e-ir.info internasional.sindonews.com kemenkeu.go.id

kemlu.go.id foreignminister.gov.au worldbank.org worldcat.org 